\title{
Testicular Seminoma, Pseudoglandular Variant
}

National Cancer Institute

\section{Source}

National Cancer Institute. Testicular Seminoma, Pseudoglandular Variant. NCI

Thesaurus. Code C40958.

A morphologic variant of testicular seminoma characterized by the presence of seminoma cells arranged in pseudoglandular patterns and few lymphocytes. 